\title{
The Journey from Compliancy to Intimate Revolt: A Kristevan Reading of Sam Shepard's Three Major Plays
}

Forough Emam*, Shideh Ahmadzadeh

English Language and Literature, Shahid Beheshti University, Tehran, Iran

Corresponding Author: Forough Emam, E-mail:forooghemam@gmail.com

\section{ARTICLE INFO}

\section{Article history}

Received: July 10, 2017

Accepted: October 11, 2017

Published: October 31, 2017

Volume: 8 Issue: 5

Advance access: October 2017

Conflicts of interest: None

Funding: None

\section{Key words:}

Intimate Revolt,

Identity Crisis,

Feminine Subjectivity,

Jouissance

\begin{abstract}
The study intends to examine three major plays of Sam Shepard-True West, Fool for Love, and A Lie of the Mind- to explore the underlying reasons for the characters' social transgression in the light of Julia Kristeva's theory of intimate revolt. Notwithstanding that all the characters feel alienated from reality and other members of society, there is a marked divergence between male and female characters in the approach they adopt to revolt against the societal norms so as to transform their lives. The findings suggest that while men seem less likely to revolt against the rules of patriarchy, it is predominantly women who embark on revolting against the psyche-numbing society to bring jouissance to their once-predetermined meaningless lives. The study comes to the conclusion that by reconnecting with their personal desire and preserving their individuality in a society that hegemonizes its subjects' identities, women engage in what Kristeva calls 'intimate revolt' and become the forces of power and change in the modern world.
\end{abstract}

\section{INTRODUCTION}

Sam Shepard, one of the most prestigious contemporary American playwrights, wrote more than fifty plays mainly concerned with the theme of identity. Depicting characters that feel both hostility and need towards others is the quintessential element in almost all of his works which reveals Shepard's fascination with the instability of identity. Since American myths are the crucial components in the formation of their identity, majority of the male characters in Shepard's three major plays are portrayed as fruitlessly attempting to live up to the American mythic archetypes of manhood. Realizing its futility and being discontent with the roles that society inflicts on them, most of the male characters suffer from a masculinity crisis which is the result of detachment from western myths. As a result of this disengagement, they undergo an identity crisis which triggers their insecurity about their true identity. Experimenting with different approaches to recover from this identity void, they become frustrated since, as stated by Shepard himself, "the possibility of somehow miraculously making [themselves] into a different person is a hoax, a futile game" (Rosen 36).

The three major plays - True West, Fool for Love, and $A$ Lie of the Mind-portray the typical Shepardian family where men who are frustrated with the roles society has imposed on them, either leave their homes or become aggressive towards their wives or partners. Men invariably leave for a desert in the hope of finding their authentic selves, but ultimately realize the futility of this quest and yearn to come back to the families they once abandoned; and women feel unfulfilled with their domestic lives and the violence directed against them by men. Majority of the scholars who have studied Shepard's three major plays dismiss them as misogynistic and view Shepard's representation of women as the crude reality of living in a patriarchal society. Ann Christine Hall, to give an instance, contends that women in Shepard's plays merely stand for the Lacanian notion of 'lack' for men and are not assertive enough to follow their own desire and wishes, and the possibility of revolting against the patriarchy is remote for both women and men. Henry Schvey draws attention to young male characters' inheriting the exercise of violence towards women, a vital feature of patriarchal societies. Schvey concludes that as long as men follow the footsteps of their fathers by leaving their families behind and going to live in a desert, the subjugation of women and psychological suffering of men will continue. He does not, however, offer a solution to this pressing problem and only underscores the fathers' profound impact on the mentality of sons in Shepard's plays. Carolyn Dana Volks analyzes the mother figures in Sam Shepard's plays and indicates how Shepard's views on the notions of masculinity and femininity have drastical- 
ly altered in his later plays. Scott C. Knowles, on the other hand, asserts that the definition of masculinity has been feminized in Shepard's recent play, Kicking a Dead Horse, but he fails to point out that Shepard's change of attitude towards the myth of masculinity had been commenced long before this play was written. Utilizing Betty Friedan's seminal book, Feminine Mystique, Audra Blaser examines the psychological wellbeing of the mothers in Shepard's plays and asserts that, as stated by Freidan, women of the fifties and sixties were immensely suffering from a problem that has no name, that the myth of motherhood in the patriarchal society is psychologically damaging women. Concluding that the myth of motherhood had only existed decades ago differentiates her study from the current article's emphasis on the ongoing struggles of women in the symbolic order.

This article intends to demonstrate that by presenting the crisis of identity in contemporary American society, Shepard attempts to challenge the status quo and indicate the failure of patriarchy in creating an authentic and stable identity for subjects. Further and even more importantly, the drastic change in Shepard's representation of female characters will be explored to demonstrate his outlook on the role of women in liberating themselves as well as men from the limitations of society. The objective of this study is to examine how the psychological problems of characters is the outcome of their status as submissive subjects in a modern society. Employing Guy Debord and Julia Kristeva's notion of 'the society of the spectacle', the research investigates how the American society, as depicted in Shepard's three major plays, distorts characters' perception of reality as well as perpetuating their mental deterioration by propagation of the myth of the West and further immersing them in unreal images by means of the mass media. Additionally, the efforts of female and male characters to liberate themselves from the repressiveness of society will be analyzed in the light of Kristeva's notion of 'intimate revolt'. The differences between the means men and women adopt to free themselves will be examined to measure their success. Whereas men have the propensity to be oblivious towards addressing the psychological hurdles the society exerts on subjects, women are more likely to tackle them by actively taking measures. Men seem to fret the prospect of redefining their selfhood, while women diligently assume the responsibility to transform their subjectivity along with stimulating others to do the same.

\section{JULIA KRISTEVA'S CONCEPT OF INTIMATE REVOLT IN SOCIETY OF THE SPECTACLE}

The necessity of revolting against social norms has always been one of Kristeva's concerns. She first introduced this concept in Revolution in Poetic Language, where she explicated how avant-garde poets employ semiotically-charged language to defy the symbolic discourse. Overtime, she extended the concept of revolt to additionally encompass the subject's standpoint towards today's lifestyle in modern societies. In her most recent book on the notion of 'revolt', The Sense and Non-sense of Revolt, she argues that revolt is "the only thing that can save us from the automation of humanity that is threatening us" (7). Inspired by Freud's concept of revolt, Kristeva redefines the notion of revolt as "the return, or access, to the archaic as access to a timeless temporality" (Sense 15). She notes that Freud's view on revolt is not associated with moral or political revolts; rather it emphasizes "the possibility that psychoanalysis has to access the archaic, to overturn conscious meaning" (Sense 16). Hence Kristeva intends to find a way back to the desire that society forbids its subjects to have access to and is consequently repressed.

Kristeva's views on the role of society in deadening the subject's psyche are also heavily influenced by Guy Debord's seminal work, Society of the Spectacle (1983). Debord asserts that in modern societies, life is manifested through a massive collection of spectacles which have supplanted real-life experiences. The spectacle is a thorough reversal of the reality of life in the real world. He adds that:

Where the real world changes into simple images, the simple images become real beings and effective motivations of hypnotic behavior. The spectacle, as a tendency to make one see the world by means of various specialized mediations (it can no longer be grasped directly), naturally finds vision to be the privileged human sense which the sense of touch was for other epochs; the most abstract, the most mystifiable sense corresponds to the generalized abstraction of present-day society. (18)

Society of the spectacle modifies the subjects' perception of reality by immersing them in empty images and false representations. Subjects become alienated from reality and normalized selfhood takes over the position of their authentic identities. The mass media plays a pivotal role in deluding the subjects with its spurious representations of reality which supersede the real pleasures and experiences of the individuals; the alienation that ensues hinders the subjects from revolting against the overruling authority and in due course contributes to the destruction of their psychic space. Destroying this space leads to "the loss of meaning ... [and] the modern subject's capacity to create" (Keltner 85). Not effectively engaged in the meaning-making process, for subjects living in society of the spectacle, psychic life is "blocked, inhibited, and destroyed" (New Maladies of the Soul 8). Kristeva, earlier in Revolution in Poetic Language, alluded to this type of society as a site of a split between semiotic and symbolic forces. She remarks that losing touch with semiotic is the key threat posed by modern societies against subjects (131). In Intimate Revolt, she adds: "the condition of modern lives-with the primacy of technology, image, speed, and so forth, inducing stress and depression- have a tendency to reduce psychical space and to abolish the faculty of representation" (11).

Revolting against the rules becomes nearly unattainable for the subjects as there is no agent of power in the society of the spectacle. Defining it as "a synonym of dignity" (Intimate 4), which takes place only if subjects confront "an obstacle, prohibition, authority or law that allows [them] to realize [themselves] as automatons and free" (Sense 6), Kristeva regards 'intimate revolt' as the only viable option for subjects to be able to experience jouissance. Society is not only alienating the subject from his actual feelings and desire, but it is as well separating the subjects from each 
other. If intimate revolt occurs among subjects who are not communicating with other members of society, Kristeva notes, "optimal connection with others" follows and ultimately leads to an "energetic urge into a dynamic of meaning with the other" (Intimate 233). Subjects, if become part of the process of meaning-making in society by revolting, emancipate themselves from the overruling authority and become active agents of power in society. When the subject deems authority as a personal element, rather than a feature associated with societal laws and norms, intimate revolt has succeeded.

Kristeva calls attention to the ability to obtain jouissance by claiming its imperativeness for subject's psychic life. She asserts in Hatred and Forgiveness that:

The art of living, taste, leisure, the so-called 'idle' pleasures, grace, pure chance, playfulness, wastefulness, our 'darker side' even, or, to put it in a nutshell, freedom as the essence of 'Being-in-the-World' prior to any 'Cause'. These are the elements that characterize European culture, and, one may hope, offer an alternative to the globalized world in which we live. (17)

Following one's desire and gaining pleasure from it, for Kristeva, is fundamentally what constitutes intimate revolt. This form of pleasure, nonetheless, is different from the pleasure as it is defined by patriarchal society. Subjects are stifled by society to not fully experience joussance as it is considered a feminine attribute. Joiussance transcends the oppressive limitations put on the experience of pleasure in the society and becomes a very personal experience which cannot be restricted by the Law. Instead of passively receiving pleasure, the extent of which is regulated by society, it becomes an active experience where one is determinedly reclaiming the right to go beyond the societal restrictions to experience the ultimate jouissance. Fantasy, as one of the mediums through which subjects can unveil their true desire and revolutionary ideas, empowers subjects to manifest those feelings restrained by society. Fantasy can be demonstrated in an array of forms including any artistic acts such as writing, dreams or unconscious wishes; subjects, by practicing these, can bring jouissance back to their lives. In the fifth chapter of Intimate Revolt entitled "Fantasy and Cinema", Kristeva contends that fantasy avails subjects to come into contact with their repressed desire, and as she stated revolt is primarily a return to the suppressed desire that society has prohibited from the social domain. Frances Restuccia, employing Kristeva's theories on contemporary cinema, remarks on the impediment of fantasy in society and states that:

As Kristeva points out, our spectacular society obstructs the formation and analysis of individualized fantasies. We are deluged with controlling images that are unfavorable to psychic liberation. The society of the spectacle's stereotypical, soap-opera images, in Kristeva's estimation, reduce the spectator to a passive consumer, making him/her the recipient of it mass-produced fantasies and thus destroying the possibility of, rather than enabling, the formulation of a particular spectator's singular fantasy-whose singularity is essential for it to do any psychoanalytic good. (109)
Subjects, by resorting to fantasy, are in a position to be part of the process of meaning-making in society and achieve jouissance which is crucial to the psychic life. They, otherwise, will be perturbed with the alienation and melancholy society inflicts upon them. As stated by Oliver, "Kristeva's prescription for depression and melancholy is what she calls intimate, or psychic, revolt" (143); Hence Kristeva firmly believes that subjects living in modern societies should experience intimate revolt as the prerequisite of enjoying a healthy psyche.

\section{MEDIA SPECTACLE AND MYTH OF THE WEST}

Majority of the male characters in Shepard's three major plays leave their lives behind in despair to live in a desert so as to liberate themselves from the psyche-numbing conditions of modern American society. The myth of the West is at the center of American identity and the open frontier guarantees that any person can have a second try. Frederick Jackson Turner remarks, in The Frontier in American Histo$r y$, that while the city is equated with inertia, the frontier is associated with primal forces. Distant from the city which is deadened by civilization, free land, viewed by Turner, is a place of authenticity and originality which provides subjects the prospect of renewal (37). The polarity between the city and the frontier that Turner notes corresponds to the opposition that Shepard creates in his plays.

Austin becomes aware of his entrapment in the city after comparing his life with that of his brother's in a desert. Lee boasts about his freedom and mocks Austin by saying:

They can't touch me anyway. They can't put a finger on me. I'm gone. I can come in through the window and go out through the door. They never knew what hit 'em. You, yer stuck. Yer the one that's stuck. Not me. (True 31)

Attempting to persuade Lee to take him to a desert, Austin discloses to Lee: “there's nothin' real down here, Lee! Least of all me!" (True 49). The city has become an accumulation of fake images that do not have any history behind them, and as Austin says:

I keep finding myself getting off the freeway at familiar landmarks that turn out to be replicas of streets I remember. Streets I misremember. Streets I can't tell if I lived on or saw in a postcard. Fields that don't even exist anymore. (True 49)

Due to the fact that the distinction between the real and the imaginary is obscured in the city, representations can be converted into real beings for subjects and accordingly alienate them from reality. Saying that "all this town does is drive a man insane" (True 56), Lee, who has lived in a desert, appears to be more alert to the destruction of the psychic space in the city.

Compared with earlier times when modernity had not yet put an end to the simplicity of life, the present situation of society, and the city in particular, results in Lee's comment on the technologies and changes occurred in the city: "Built up? Wiped out is more like it. I don't even hardly recognize it (True 11). Same as his childhood home, situated in "Southern California suburb, about 40 miles east of Los Angeles" (True 3), Austin lives "up in the North Country where 
things are calm" (True 39). Living in a suburban area where life, as Lee states, centres around owning "the house, the car, the whole slam" (True 9), the psyche-numbing aspect of the modern urban life becomes more evident. Even Lee, skeptical about finding contentment in the city, compares the house of a neighbor with the pictures "they got in the magazines. Blonde people movin' in and outa' the rooms, talkin' to each other" (True 12). The false representations circulated by the mass media lead to the automation of subjects who are "livin' the life. Indoors. Safe" and believing that they are "in a paradise" (True 39).

The only references to reality, for Lee, seem to be movie scenes. He looks up to Kirk Douglas in the Western movie Lonely Are the Brave as his role model. In his pursuit of reality and authenticity, he turns to Western movies which have no reference to actual happenings or characters. Jean Baudrillard's travel diary of his visit to America documents the inauthenticity of the West and American Cinema:

It is not the least of America's charms that even outside the movie theatres the whole country is cinematic. The desert you pass through is like the set of a Western, the city a screen of signs and formulas ... The American city seems to have stepped right out of the movies. (56)

The authenticity that Lee expects to accomplish through the medium of Western movies is based on images that have no 'real' reference. The urge to return to the archaic as access to a timeless temporality, as Kristeva wishes for, becomes unattainable in a society where the only references to the past are false representations in the mass media which are mainly stereotypes. Lee's “"“true-to-life Western" hero" (True 19), therefore, cannot serve him in his discovery of his authentic self.

The myth of the frontier is an essential component of the American identity. Austin has grown up with the idea of a promised land where one can have a prospect of regenerating his life. At the beginning of the play, he disparaged Lee by saying that he has

been camped out on the desert for three months. Talking to cactus. What's he know about what people wanna' see on the screen! I drive on the freeway every day. I swallow the smog. I watch the news in color. I shop in the Safeway. I'm the one who's in touch! Not him! (True 35)

Yet, following losing his identity as a screenwriter, he goes through an identity crisis and wishes to go to a desert given the fact that "There's nothing down here for me. There never was" (True 49). Every subject needs to have a reference to maintain his identity; he, if loses the reference as the core of his selfhood, loses his sense of identity as well. In the society of spectacle, where real is constituted of a chain of empty images, every meaning can be reconstituted from one image to another, as there is no actual signified to be the reference in the system of signs. In True West, Austin loses his position as a screenwriter in Hollywood, and promptly his brother, with no prior experience, takes over. Lee brags about his new status by saying: "I'm a screenwriter now! I'm legitimate" (True 37). Hence Austin decides to go to a desert in pursuit of a stable identity with an authentic reference that cannot be altered easily.
In society of spectacle, even Lee who has "raw talent" (True 34) and is "speaking from experience" (True 35) is compelled to modify his script to accommodate to the standards of an American movie. His manager informs him that even though his script has "the ring of truth" and something about "the real west" and "the land" (True 35), what they count on is profit by representing stereotypical images of the West so as to preserve the myth in society. He tells Lee: "In this business we make movies, American movies. Leave the films to the French" (True 30). Realizing how Hollywood distorts the vision of the West in its movies, Lee discovers that the myth of the frontier, vital to the American identity, is not 'real' and cautions Austin against "fantasies of a long lost boyhood" (True 40). Living in a society where reality cannot be differentiated from false representations and copies are preceding the real, subjects can suffer from loss of referntiality and consequently fail to engage in the process of meaning-making as Kristeva alerts. The simulation of a desert in True West contributes to a psychic dead-end for both brothers, since the frontier, like the city, has been converted into an unreal place for subjects with no likelihood of finding authenticity in its false representations.

The fantasy of redemption in a desert has ultimately been shattered for both brothers. Lee confesses to Austin that moving to a desert will not solve their psychological problems since "Nobody can disappear. The old man tried that. Look where it got him" (True 41). Austin realizes the truth as well when he shouts at his manager that "there's no such thing as the West anymore! It's a dead issue!” (True 35). To quote Mark Busby, "Shepard's plays demonstrate ... the two sides of the American myth: the promise of the dream of regeneration on the American frontier and the recognition that the dream has often been violent and destructive ... Continuing to entrap and destroy" (91-92). Both brothers, facing this uncertainty, have to come to terms with their true selves and identify another approach to cope with their existential crises.

The male characters in A Lie of the Mind and Fool for Love, as well, have gone to live in a desert. Longing for human connection, Old Man, pointing to an invisible picture of Barbara Mandrell, says: "That's realism. I am actually married to Barbara Mandrell in my mind" (Fool 27). Living in a cabin that reeks of alcohol, Jake's father has taped the pictures of his children along with a number of singers and actors to the walls of the cabin, trying "to make a family out of [them] all" (Lie 90). Attempting to alienate themselves from reality by relocating to a desert, they both are outwitted by society of the spectacle when they turn to images that have no authenticity or existence outside the system of signs to find solace.

\section{MEN'S INTIMATE REVOLT: CONSTRUCTIVE METAMORPHOSIS}

One of the modes of expression for intimate revolt, for Kristeva, is linguistic articulation. If one can manifest "the interrogation and experience of affective suffering" through the agency of words, linguistic articulation can be deemed "the talking cure" (Keltner 66) which is an intimate experience. 
Despite the fact that majority of the male characters in Shepard's three major plays are not very much concerned with revolting against the norms of the symbolic order, the ones that opt to resist may adopt a means of expression already hegemonized by the society of the spectacle and therefore fail in their attempt. The myth of the west plays a significant role in the lives of the male characters, however they eventually realize the futility of it for it has been appropriated by the society of the spectacle.

Lee comes to understand the fallacy of the West by beginning to work on a script as a screenwriter. Although he has experienced the realities of living in a desert, since he is working for Hollywood, he should preserve the mass-produced fantasies of Hollywood industry which do not necessarily correspond to the reality of living in the frontier. Even the professional screenwriter, Austin, does not make use of linguistic articulation as a means of emancipation from the detrimental effects of the symbolic order. He is simply a mere instrument in the industry to reproduce false fantasies and be paid with "Hollywood blood money" (True 8). Lee who has understood the mechanism of Hollywood refers to Austin as "a parasite" who lives "offa" other fools" (True 22 ) and moreover ridicules the mass media when he tells his brother that by stealing TVs from the neighbors he is "doin' them a service. They don't need their televisions" (True 22). As noted by Noëlle McAfee, "in the society of the spectacle, people are tools of the economy; their desires are not their own; desires are manufactured as surely as are the commodities meant to fulfill them" (108).

Austin's manager dismisses his script since "nobody's interested in love these days (True 35) and would rather invest in Lee's script which is "real commercial. Full a' suspense" (True 15). The manager's concern about the movie's financial gain is reminiscent of Debord's view on the politics of production in the society of the spectacle:

The worker does not produce himself... he produces an independent power. The success of this production, its abundance, returns to the producer as an abundance of dispossession. All the time and space of his world become foreign to him with the accumulation of his alienated products. The spectacle is the map of this new world, a map which exactly covers its territory. (31)

Writing becomes an impotent outlet for acknowledging one's desire in view of the fact that the society of spectacle "subjugates living men to itself to the extent that the economy has totally subjugated them ... It is the true reflection of the production of things, and the false objectification of the producers" (Debord 16). Kristeva defines writing as a practice that can be analogous to political revolution only if it functions as a "structuring and de-structuring practice, a passage to the outer boundaries of the subject and society" (Poetic Language 17); this is the only method of writing that can bring jouissance and transformation to the subject. Even though Austin and Lee view the typewriter as a figurative battlefield so as to find a stable identity, their attempts are futile since:

Austin has merely provided his brother with a constructive, yet highly problematic, outlet for his creativity.
The frustration, though, finds release in the creation of art ... yet the ambivalence between the purity and passion of the artist (Lee) and the dazzling artificiality of Hollywood, in general (Austin and Saul), is ever-present. (Blackburn 48)

Only after Austin loses his status in the symbolic order he begins to understand that to have an authentic selfhood, he needs not to look for an external reference, since in the society of spectacle every reference is a false representation that cannot be taken hold of. Austin, as a subject, needs to retreat from the outer world and look within to a find an approach to revolutionize his life and be able to follow his 'real' desire. When the opportunity of revolutionizing one's self in the frontier is denied to an American subject, as rightly observed by John M. Clum, the salvation can only be materialized if the subject's "reference point remains himself" (179). An intimate revolt, therefore, must take place by examining 'the inner realm' and becoming involved with the repressed desire.

Both brothers recognize what they lack in their lives is accepting the Other in their selves and start to obtain the other's characteristics. Alluding to this recognition of the Other, Austin tells Lee that "we're the same person .... one and the same" (True 37). By acknowledging the need for each other, they can overcome society's estrangement of subjects from each other and as Austin remarks enjoy each other's company for the first time (True 37). Although the ending of the play might appear to be obscure (Lee and Austin, who seemed to have reconciled, are fighting with one another), their conflict is demonstrative of the open-ended struggle between the semiotic and symbolic which is of utmost importance to the process of meaning-making. By embracing the Other, one prevails over the obstacle of alienation imposed by society and is able to ultimately experience jouissance which is vital for having a healthy psyche. Among Shepard's male characters, Austin and Lee are the only characters who recognize the need for intimate revolt independently. The rest of the male characters either stay oblivious to the psyche-numbing society which represses their desire or are enlightened by a female character who draws their attention to the limitations and obstacles needed to be overcome.

The father of Austin and Lee and the father of Jake are among the old generation that leave their families and lives in the city and move to a desert. Older men in most of Shepard's plays are not keen on dismissing the patriarchal ideal of masculinity which exerts influence on their ideologies and identities. Both of them address their psychological issues by alienating themselves from reality by living outside society. Rather than acknowledging the complications in the society or themselves, they detach themselves from reality. Since the separation from reality results in the destruction of psychic space and loss of meaning, both men attempt to comfort themselves by drinking heavily to cease to think of the 'real' lives they left behind in the city. Jake's father is disengaged from reality; when Sally and Jake pay him a visit, he does not even recognize his own offspring.

Living in a cabin that reeks of alcohol, Jake's father has taped the pictures of his children and numerous singers and 
actors to the walls of the cabin, trying "to make a family out of [them] all" (Lie 90). Having lost all his money, he cannot be enough drunk to forget the reality and therefore he turns to pictures, the false images of his 'real' family that he abandoned, to forget the guilt and pain he still feels. Kristeva comments on how subjects' last resort can be empty images, when even alcohol and drugs do not suffice:

If drugs do not take over your life, your wounds are "healed" with images, and before you can speak about your states of the soul, you drown them in the world of mass media. The image has an extraordinary power to harness your anxieties and desires, to take on their intensity and to suspend their meaning. It works by itself. (New Maladies 8)

This approach evidently is not effective since according to his daughter he "looked real weak and vulnerable" (Lie 90) just as Lee's father who not only has lost all his teeth, a physical embodiment of identity, but also left the false ones in a bar. Observing his father's attempt to alienate from reality, Lee states: "he's not gonna change but I will. I'll just turn myself right inside out" (True 25). The old generation's incompetence to reconceive themselves can be one of the motives for the younger generation's determination to make a change in their lives.

A number of sons, including Eddie and Jake, become to some extent aware of the destructive effects of the discourse of patriarchy with the help of Beth and May and identify the obstacles Kristeva argues needed to be overcome. Yet, they are not forceful enough to overcome these obstacles and have to leave since there are other men, the likes of Frankie and Martin, who are willing to forego the characteristics imposed on them by patriarchy. It seems that in achieving intimate revolt, the only viable solution to free one's self from the limitations of society that deaden the psyche, men are not immensely successful. The cause can be their identities which are predominantly defined by symbolic traits. As the privileged subjects of the symbolic order, they are less informed about the deficiencies of society and are less likely to revolt against its rules. And even if they realize the shortcomings, with assistance from a woman, they cannot effortlessly transform themselves, since they have to dismiss some aspects of their identities and redefine their selfhood.

\section{WOMEN'S INTIMATE REVOLT: SUBVERSIVE PROGENIES}

Women, marginalized and excluded from power or knowledge in the symbolic order, are more likely to experience jouissance by having access to the semiotic realm and revolting against the rules and norms of the symbolic order. When women challenge the Law of the patriarchy, entitling women only as mothers, and free themselves from the identity that the symbolic realm imposes on them, they participate in what Kristeva calls intimate revolt.

Even though Mom in True West has a very limited stage time, she thoroughly expresses her frustration with the roles society has enforced on her. In the same manner as the male characters, who leave their families to move to a desert, she leaves her house to visit Alaska but only temporarily. Given the fact that she is the very first self-sufficient female character in Shepard's plays, her short visit to a frontier can be as revolutionary as men's permanent lives in a desert. However she cuts her trip short, because she seems to be ill at ease with her newly found freedom. Her dependence on her motherly role may trigger her to come back to the house, yet she does not seem to be confined to the roles that society requires from a mother. At the end of the play, she leaves her house, feeling being there is "worse than being homeless" (True 58), to pursue what she personally desires.

Following the characterization of Mom, Shepard created May in Fool for Love, who according to Shepard is the strongest female character he ever created (Roudane 73). Unlike the previous women in Shepard's works, she is not a supplementary personage whose existence is entirely established by her connection to the men in the play. While she has tried to persuade Eddie that he needs to recognize his need for her, Eddie is under the influence of his father, the representative of the patriarchal ideology, that he does not need to change his views. Becoming aware that she cannot change Eddie, May resolves to start a new life and date Martin who, compared with Eddie, is more thoughtful of May's needs and desire. In her pursuit of revolt, May attempts to convince the male characters, specifically Eddie, to participate, but the "optimal connection with others" (Intimate 233) that Kristeva hopes for becomes impossible to be achieved. Instead May liberates herself from the toxic ties of the relationship with Eddie and carries out what Kristeva remarks should be the most essential aspiration of every subject: Maintaining her individuality and following her personal desire. Even though Shepard's first attempt to create an independent female character was not immensely successful, his effort to acknowledge the individuality of female characters should be accredited. After writing Fool for Love, Shepard began to write his last family play, A Lie of the Mind, where the number of female and male characters are, for the very first time in his career, equal., In A Lie of the Mind, there are three main female characters -Beth, Meg, and Lorraine- who are not one-dimensional and as subjects with complex personalities psychologically and ideologically evolve throughout the play.

While living with Jake, Beth tried to withdraw from her monotonous life by being an actress and materializing her wish to be more than a housewife. Eddie is alarmed by Beth's fluid subjectivity as an actress and feels intimidated by her expressiveness of female sexuality. Since Beth is manifesting the semiotic forces within her by engaging in artistic activities, Eddie, as the privileged member of the patriarchal society, attempts to censor her desire by physically abusing her. Rather than retreating from the symbolic order, Beth looks for a means to bring the semiotic back to the symbolic realm, whether by becoming an actress and materializing her individual wishes or by being with Frankie, a man who seems to be acceptant of semiotic forces in his identity. In The Future of Revolt (1998), later included in Intimate Revolt, Kristeva contends that every form of intimate revolt aims at one objective: "From prayer to dialogue, through art and analysis, the capital event is always 
the great infinitesimal emancipation: to be restarted unceasingly" (Intimate 223). Undergoing what Rosemarie Banks considers "individuation process at work" (233), Beth leaves her husband to reconsider her status in society. Women in Shepard's plays, unlike male characters, do not accomplish intimate revolt by transforming meaning and social connections through art and writing; rather they opt to demonstrate their singularities by being dynamically involved in society.

In accordance with Kristeva's argument that "revolt ... refers to a state of permanent questioning, of transformation, change, an endless probing of appearances" (Intimate 120), Beth goes through a number of alterations in her appearance that indicate her rebellious attitude towards overcoming the obstacles which will ultimately bring her jouissance. While in the beginning of the play Jake says that Beth used to wear spiky high heels and not wear any underpants or bra (Lie 8), back at her childhood house, she is "dressed in one of Baylor's faded red plaid shirts, way too big for her" (Lie 42). Her parents have attempted to make her look conservative, just as her husband did by physically harassing her. When she sees Frankie, however, she takes the shirt off and talks about the power of clothes for men. She tells Frankie that a man is fearful of his own shirt, "he puts his scary shirt on so it won't scare himself. He can't see it when it's on him. Now he thinks it's him" (Lie 74). She revolts against the norms of society that expects her to be a submissive powerless woman by wearing the shirt and redefining the meaning of it by saying "shirt brings me a man. I am a shirt man .... Like father .... Like brother" (Lie 75). Calling it custom - a play on the word costume - she pokes fun at the idea of masculinity as only a representation that can be acquired by anyone. She startles her father by wearing a very short and tight dress at the end of the play; the fact that her father tells her she looks "like a roadhouse chippie" (Lie 111) demonstrates her fluidity towards her representation which is line with Kristeva's interpretation of intimate revolt.

Lorraine in A Lie of the Mind is more revolutionary than Beth since she makes a decision to burn the family house, leave everything behind and start a new life without any man. Although it may seem that she is separating herself from reality, given the fact that she is going to find her ancestors in Ireland indicates that her departure is a symbolic act emphasizing her desire to be reconnected with "the archaic as access to a timeless temporality" (Kristeva, Sense 15). Her symbolic withdrawal from the society of the spectacle can also be understood as her desire for the annihilation of the symbolic order; nonetheless if subjects live in a community where they cannot keep their psyches alive "there is not a strong possibility for a successful political revolt. If subjects do not hold on to their inner realms and singularities, any political revolution will lead to bureaucratization and terror" (Keltner 118). Consequently, Lorraine starts with transforming what Kristeva contends the prerequisite of approaching political revolt: "Start[ing] from the small things, the small notions" (Guberman 15). Compared with Mom in True West, Lorraine is not only reinventing her own life but is engaging in what Kristeva considers an "energetic urge into a dynamic of meaning with the other" (Intimate 233), manifested by her urging family members to revitalize their lives.

While Lorraine has a very troubling relationship with her daughter, Sally, up to the end of the play, they reconcile when they both realize that what has alienated them from each other is the men of the family. Lorraine, who used to hold Sally responsible for killing her father (Lorraine's husband), comes to the realization that his death was his own fault. She tells her daughter:

All the junk in this house that they left behind for me to save. It's all goin'. We'll make us a big bonfire. They never wanted it anyway ... That was just a dream of theirs ... They dreamed it all up just to keep me on the hook. Can't believe I fell for it all those years. (Lie 96)

Lorraine's husband, similar to majority of the male characters in Shepard's plays, has accelerated his own demise by alienating from reality and then turning to alcohol after realizing that the frontier does not resolve his identity crisis. What grew these two women apart was a fallacy of the society of the spectacle that led to Lorraine's husband's death. As stated earlier, society separates the subjects from each other and only if intimate revolt takes place the subjects can achieve freedom and reconnect with the other members of society. Lorraine and Sally revolt against the rules of the society by first acknowledging the responsibility of the symbolic order for the death of Lorraine's husband and then making the decision to go to Ireland together.

Another female character in A Lie of the Mind makes a decision more in line with what Kristeva hopes women as mothers do to achieve their desire without cutting ties with the role of motherhood as it is expected from them in the symbolic order. Realizing the restrictions imposed on her by the patriarchal society, Meg attempts to reinvent her identity without abandoning her family. She rebuilds her subjectivity in a way that includes aspects other than being a mother or housewife. When Baylor asks her to, as always, help him put his socks on, she "crosses slowly over to his socks, picks them up off the floor, holds them up in the air" (Lie 78). Rather than kneeling in front of him as she used to do, she places the socks on Balylor's lap and walks away. In other words, she is determined to redefine her subjectivity by voicing her newly formed beliefs while consciously staying with her family. By doing so, she enables her husband to become aware of her new selfhood and instructs him to adapt himself to the new discourse of power in the family structure. As stated by Keltner, "Kristeva's concept of intimate revolt is not the accomplishment of a solitary individual, but rather depends on relations to others" (105). With Meg's non-radical attitude, Baylor has the opportunity to stay with his family and needs not to follow the tragic path of male characters in Shepard's works which only sparks frustration and identity crisis.

Even though these methods of manifesting their discontent may not appear to be extremely revolutionary, as Kristeva states, as long as one is able to have "the capacity for enthusiasm, doubt, and the pleasure of inquiry" (Sense 19), that individual is revolting against the society of the spectacle. Moreover, she stresses the importance of both psychological 
(intimate) and political revolt; by starting with transforming "the minimal components that constitute the speaking being" (Guberman 15), the possibility of a successful political revolt in society becomes stronger. Reconnecting with their personal desire and maintaining their individuality in the society of the spectacle that hegemonizes its subjects' identities, women become the agents of power and transformation in the modern world who revolutionize the lives of themselves as well as that of the male characters'.

\section{CONCLUSION}

Majority of the male characters in Shepard's three major plays leave their lives and partners behind to find an authentic identity in a desert. Yet, they finally realize that they have been deluded by the society of the spectacle and its hegemony of media and the reinforcement of the false representation of the frontier. Upon this realization, a number of the male characters try to overcome these societal obstacles as well as the alienation from reality to ultimately find their true identity. A myriad of them, however, seem negligent towards the shortcomings of the patriarchal society. Enjoying a superior position which offers an array of merits, men fail to detect the drawbacks of the patriarchy. Attempting to ensure the stability of their own selfhood, they find it challenging to tackle these hurdles and transform themselves. Unlike the male characters, women oppose the Law of the patriarchy, labeling them only as mothers, and emancipate themselves from the identity that the symbolic realm imposes on them by following their personal desire, maintaining their individuality in the society of the spectacle which stifles the singularity of subjects, and reconfiguring the meaning of female subjectivity. Engaging in what Kristeva calls intimate revolt', women become the agents of change in society by revolutionizing their own lives as well that of men's.

\section{REFERENCES}

Banks, Rosemarie. "Self as Other: Sam Shepard's Fool for Love and A Lie of the Mind." Feminist Rereading of Modern American Drama. Edited by June Schlueter. London; Toronto: Associated UP, 1989: 227-40.

Baudrillard, Jean. America. Translated by Chris Turner. London: Verso, 1988.

Blackburn, John. "Portrait of the Artist: Sam Shepard and the Anxiety of Identity." MA thesis, University of Virginia, 1996.

Blaser, Audra. "Beyond Bedrooms and Kitchens: A Critical Analysis of the Mother Figures in Sam Shepard's Family Plays." MA thesis, University of Colorado, 2004.

Busby, Mark. "Sam Shepard and Frontier Gothic." Frontier Gothic: Terror and Wonder at the Frontier in American Literature. Edited by David Mogen, Scott P. Sanders, and Joanne B. Karpinski. London: Associated UP, 1993: 84-93.
Clum, John M. "The Classic Western and Sam Shepard's Famiy Sagas." The Cambridge Companion to Sam Shepard. Edited by Matthew Roudané. Cambridge: Cambridge University Press, 2002: 171-188.

Debord, Guy. Society of the Spectacle. Detroit: Black and Red, 1983.

Guberman, Ross Mitchell, editor. Julia Kristeva Interviews. New York: Columbia University Press, 1996.

Hall, Ann C. A Kind of Alaska: Women in the Plays of $O^{\prime} N e i l l$, Pinter, and Shepard. Carbondale: Southern Illinois University Press, 1993.

Keltner, Stacy. Kristeva: Thresholds. Cambridge: Polity, 2011.

Knowles, Scott C. "Locating American Masculinity With(out)in the Male: Sam Shepard's Kicking a Dead Horse, Neil LaBute's Reasons to Be Pretty, and Sarah Ruhl's Late: A Cowboy Song." MA thesis, The Florida State University, 2010.

Kristeva, Julia. Hatred and Forgiveness. New York: Columbia University Press, 2010.

Kristeva, Julia. Intimate Revolt: The Powers and Limits of Psychoanalysis. New York: Columbia University Press, 2002.

Kristeva, Julia. New Maladies of the Soul. New York: Columbia University Press, 1995.

Kristeva, Julia. The Revolution of Poetic Language. New York: Columbia University Press, 1984

Kristeva, Julia. The Sense and Non-sense of Revolt. New York: Columbia University Press, 2000.

McAfee, Noëlle. Julia Kristeva. New York: Routledge, 2004.

Oliver, Kelly. Colonization of Psychic Space: A Psychoanalytic Social Theory of Oppression. Minneapolis: University of Minnesota, 2004.

Restuccia, Frances L. The Blue Box: Kristevan/Lacanian Readings of Contemporary Cinema. London: Continuum International Pub. Group, 2012.

Rosen, Carol. "Silent Tongues: Sam Shepard's Explorations of Emotional Territory." Village Voice, 4 August 1992, 35-36.

Roudané, Matthew. "Shepard on Shepard: An Interview." The Cambridge Companion to Sam Shepard. Edited by Matthew Roudané. Cambridge: Cambridge University Press, 2002: 64-80.

Schvey, Henry I. "A Worm in the Wood: The Father-Son Relationship in the Plays of Sam Shepard." Modern Dra$m a, 36,1,1993,12-26$.

Shepard, Sam. "A Lie of the Mind." A Lie of the Mind and The War in Heaven. New York: New American Library, 1987, pp. 1-132.

Shepard, Sam. "Fool for Love." Fool for Love and Other Plays. New York: Bantam Books, 1984, pp. 19-57.

Shepard, Sam. "True West." Sam Shepard: Seven Plays. New York: Bantam Books, 1981, pp. 1-59.

Turner, Frederick Jackson. The Frontier in American History. New York: Holt, 1963.

Volks, Carolyn Dana. "The Representation of Women in the Plays of Sam Shepard." MA thesis, Rhodes University, 1994. 